\title{
Trophic niche of two co-occurring ophiuroid species in impacted coastal systems, derived from fatty acid and stable isotope analyses
}

\author{
Aline Blanchet-Aurigny ${ }^{1, *}$, Stanislas F. Dubois ${ }^{1}$, Claudie Quéré2 ${ }^{2}$, Monique Guillou ${ }^{3}$, \\ Fabrice Pernet ${ }^{2}$ \\ ${ }^{1}$ IFREMER, Laboratoire d'Ecologie Benthique, Département Océanographie et Dynamique des Ecosystèmes, \\ Centre de Bretagne, BP70, 29280 Plouzané, France \\ ${ }^{2}$ IFREMER, Laboratoire de Physiologie Fonctionnelle des Organismes Marins, LEMAR UMR CNRS IRD 6539, \\ Centre de Bretagne, BP70, 29280 Plouzané, France \\ ${ }^{3}$ Institut Universitaire Européen de la Mer, Université de Bretagne Occidentale, LEMAR UMR CNRS IRD 6539, \\ place Nicolas Copernic, 29280 Plouzané, France
}

\begin{abstract}
The trophic niches of 2 common co-occurring ophiuroids, Ophiocomina nigra and Ophiothrix fragilis (Echinodermata, Ophiuroidea), in 2 contrasting coastal systems of Brittany (France) were investigated. We used a combination of fatty acid biomarkers derived from neutral lipids and stable isotopic compositions to explore the contributions of oceanic versus continental inputs to the ophiuroids' diet. We investigated 2 different systems with an inshore versus offshore comparison. We sampled potential food sources and surveyed organisms every 2 mo for $1 \mathrm{yr}$. Spatio-temporal variations in stable isotopes and fatty acid profiles of the ophiuroids were generally low compared to interspecific differences. Fatty acid markers showed that both ophiuroids relied on diatom inputs. However, a more $\delta^{15} \mathrm{~N}$-enriched isotopic composition as well as a more balanced plant- versus animal-derived fatty acid composition in $O$. nigra suggest that a broader range of food sources are being used by this species irrespective of location or sampling time. The positive correlation between the 18:1n-9/18:1n-7 fatty acid ratio and $\delta^{15} \mathrm{~N}$ values indicates a higher trophic position for $O$. nigra (suggesting an omnivorous feeding mode), whereas $O$. fragilis appears to be more herbivorous. Moreover, the low polyunsaturated/saturated fatty acid ratio associated with elevated bacterial fatty acid markers indicates that $O$. nigra preferentially consumes detritus, while $O$. fragilis relies more on fresh phytoplankton-derived material. Both stable isotope and fatty acid analyses suggest that terrestrial inputs do not contribute significantly to the diet of these ophiuroids. However, phytodetritus derived from decomposing green macroalgae contributed to the diet of $O$. nigra in the Bay of Douarnenez.
\end{abstract}

KEY WORDS: Echinoderm · Feeding ecology $\cdot$ Ophiocomina nigra $\cdot$ Ophiothrix fragilis $\cdot$ Trophic markers $\cdot$ Green algae

Resale or republication not permitted without written consent of the publisher

\section{INTRODUCTION}

Echinoderms often exhibit high population density fluctuations - also called 'outbreak' or 'die-off' events - in coastal and deep water ecosystems, where they play key structural and functional roles.
Such events are often facilitated by anthropogenic factors (e.g. nutrient inputs, over-fishing) and the life history traits of the echinoderms (adult feeding mode, high fecundity, high longevity, larval type), and could trigger dramatic changes in the marine ecosystem structure (Uthicke et al. 2009). 
In European coastal waters, benthic assemblages are often dominated by dense populations of benthic suspension-feeders as well as opportunistic depositfeeders which can take advantage of the high primary production (Hily 1991, Carvalho et al. 2011). In widespread habitats, ophiuroids account for a majority of the benthic biomass, where they play a key role in the coupling of benthic-pelagic systems (Allen 1998). The Land's End of Brittany (France) hosts dense populations of both Ophiocomina nigra and Ophiothrix fragilis (Echinodermata, Ophiuroid) (Abildgaard), which occur either in mixed or monospecific beds across a wide range of sedimentary features (Hughes 1998). Although this species assemblage is reported to be stable over time and is usually dominated by O. fragilis (Hily 1991), recent investigations in Brittany revealed long-term density changes and spatial shifts in $O$. nigra and $O$. fragilis beds between 1987 and 2011 (Blanchet-Aurigny et al. 2012a, Guillou et al. 2013). It was hypothesized that a combination of changes in food supply and the biological traits of $O$. nigra were a key factor of its proliferation in this area (Blanchet-Aurigny et al. 2012a). As demonstrated with other echinoderms, it was suggested that flexibility in feeding habits (Thrush \& Cummings 2011) as well as an increase in fecundity and fertilization (Sewell \& Levitan 1992) contributed to the species' success. While both adult ophiuroid species are reported to be suspensionfeeders (Aronson 1989), O. nigra exhibits a much wider trophic plasticity and displays a versatile feeding behavior (Fontaine 1965). Indeed, O. nigra is more mobile at the sediment-water interface and commonly consumes a variety of deposited material (Vevers 1956), or behaves as a scavengerous species, foraging on detritus or carrion (Nagabhushanam \& Colman 1959).

In coastal marine and estuarine systems, the energy supply for benthic consumers is derived from a high diversity of food sources, with strong variation in space and time (Peterson 1999). Such ecosystems often exhibit a great diversity of primary producers which are conveyed into higher trophic levels (Mann 1988). During the last several decades, abundant production of green macrophytes Ulva sp. have been an increasing issue in Brittany's coastal waters (Dion \& Le Bozec 1996, Merceron et al. 2007), providing a large supply of macroalgae detritus for many species that potentially benefit. Benthic invertebrate assemblages are often dominated by dense populations of benthic suspension-feeders as well as opportunistic deposit-feeders taking advantage of this abundant primary production (Hily 1991, Carvalho et al. 2011).
Stable isotope analysis has been successfully used to study the trophic links from primary producers to higher trophic levels, indicating different utilization of food sources by benthic and pelagic invertebrates (Dubois \& Grall 2013). Indeed, stable isotope signatures in consumers provide time-integrated information on food sources. The carbon and nitrogen isotope ratios in an animal's tissues closely reflect those in its diet, with a slight enrichment of heavier isotopes $\left({ }^{13} \mathrm{C}\right.$, ${ }^{15} \mathrm{~N}$ ) due to preferential respiration of lighter ${ }^{12} \mathrm{C}$ and excretion of lighter ${ }^{14} \mathrm{~N}$ (DeNiro \& Epstein 1978). Lipid markers also provide complementary information on the type and quality of resources assimilated by animals (Dalsgaard et al. 2003). Marine bacteria, diatoms, dinoflagellates, terrestrial inputs, macroalgae and vascular plants show different combinations of specific fatty acids. As recently discussed, the use of fatty acids for dietary studies can be constrained by the degree to which the fatty acid composition of an organism is obscured by factors that have the capacity to alter metabolic processes (Kelly et al. 2008, 2009, Guest et al. 2010, Dethier et al. 2013). In such cases, the use of fatty acid composition from neutral lipid contents (storage lipids) alone may reduce confusion on dietary interpretation (Pernet et al. 2012, 2014). When used together, fatty acid and stable isotope techniques show promise for resolving the trophic ecology of complex aquatic ecosystems (Kharlamenko et al. 2001, Kelly \& Scheibling 2012).

In the present study, we aimed to investigate the trophic niche of the 2 ophiuroid species $O$. nigra and $O$. fragilis, using stable isotope and fatty acid biomarkers. We compared temporal variations in diet composition of the ophiuroids at sites with different hydrodynamic conditions and levels of anthropogenic influence (e.g. nutrient inputs, green macrophytes). In the inshore zone of the Bay of Douarnenez, where the green algae Ulva sp. proliferates, we evaluated whether the expanding population of O. nigra benefits from this resource. We also examined patterns of resource overlap to determine the possibility of resources competition between species, as well as to better understand the success of $O$. nigra over $O$. fragilis in this region.

\section{MATERIALS AND METHODS}

\section{Study areas}

The Bay of Brest (BB) is a shallow marine coastal system of $180 \mathrm{~km}^{2}$ that is connected to the Atlantic Ocean by a narrow opening $1.8 \mathrm{~km}$ wide (Fig. 1). 


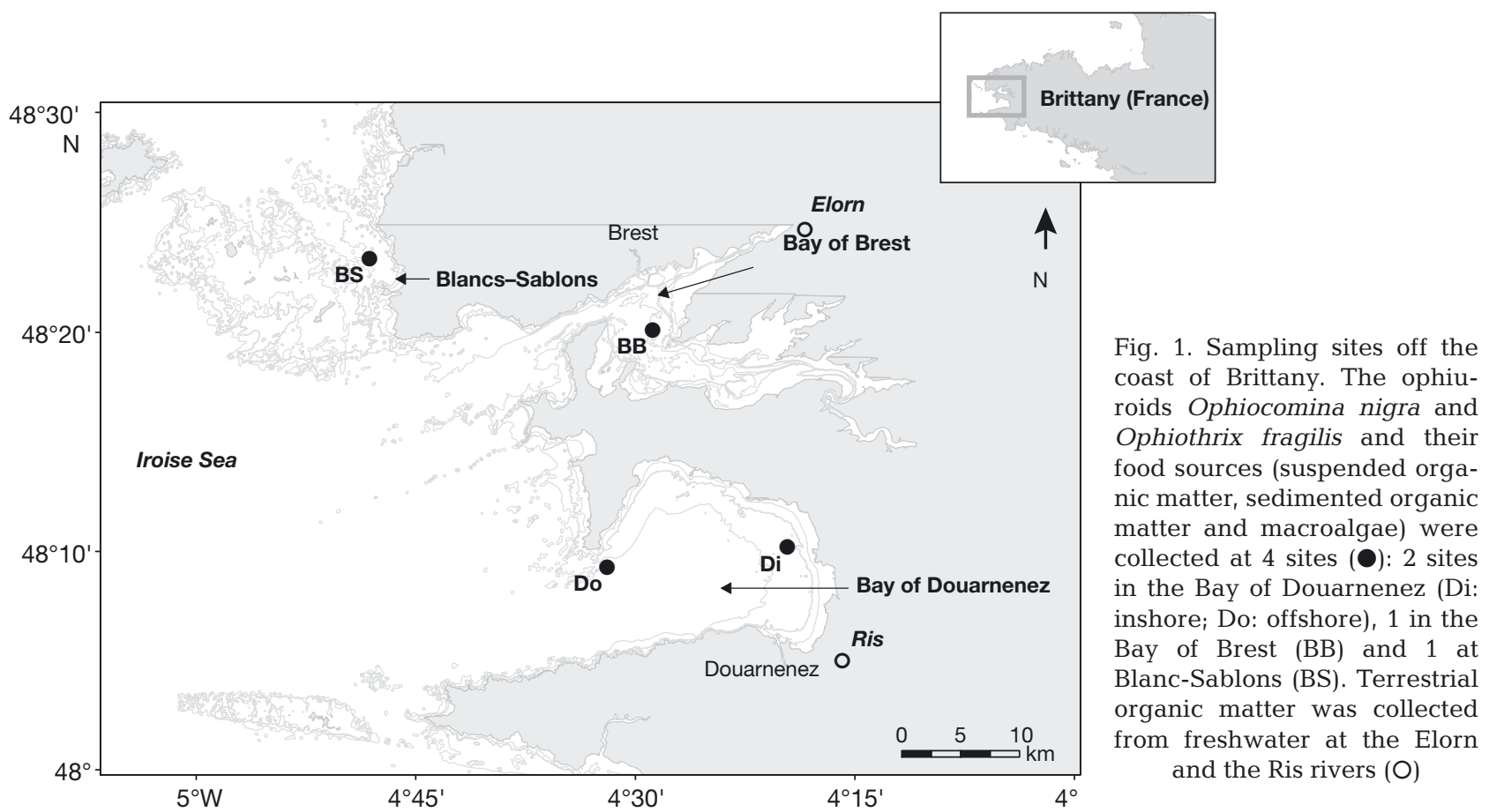

This Bay is a macrotidal system that receives anthropogenic nutrient inputs from 2 rivers (Aulne and Elorn), which are facilitated by high hydrodynamic mixing conditions (Le Pape et al. 1996). The Bay is characterized by large amounts of phytoplankton biomass, and benthic communities are dominated by dense populations of suspension-feeders (Hily 1989, 1991). To the north of the BB, the site of BlancSablons (BS) experiences strong hydrodynamic conditions and is directly exposed to oceanic inputs. South of these 2 sites, the Bay of Douarnenez is a shallow marine coastal system of about $350 \mathrm{~km}^{2}$ connected to the Atlantic Ocean by an opening $9 \mathrm{~km}$ wide. The inshore zone of the Bay of Douarnenez (Di) is highly impacted by green macroalgae blooms, also called 'green tide' (Merceron et al. 2007). The offshore zone of the Bay (Do) is influenced by strong hydrodynamic oceanic conditions.

\section{Sample collections}

Food sources and ophiuroid specimens were sampled every 2 mo between June 2010 and April 2011 in $\mathrm{BB}, \mathrm{BS}$, and in Do and Di. Four potential food sources were analyzed: suspended particulate organic matter (SPOM), terrestrial organic matter (TOM), sediment organic matter (SOM) and the green macroalgae Ulva sp. in the Bay of Douarnenez. Water samples for SPOM analyses were collected at $50 \mathrm{~cm}$ depth at high tide, close to the ophiuroid bed. Freshwater samples were collected from 2 rivers (Elorn and Ris) for TOM analyses. Water was pre-filtered through a $200 \mu \mathrm{m}$ mesh screen to remove the largest particles, and then filtered through pre-combusted Whatmann GF/C filters. The surface sediment of $1 \mathrm{~cm}$ was scraped from a core for SOM analyses. Sediment samples were sifted through 500 and $200 \mu \mathrm{m}$ mesh screens to remove the largest particles and frozen at $-80^{\circ} \mathrm{C}$. Sediment samples of the $<200 \mu \mathrm{m}$ fraction were then freeze-dried and grounded to a fine powder. Finally, samples of Ulva sp. (stranded and floating blades) were collected in the Bay of Douarnenez, cleared of epibionts and frozen at $-80^{\circ} \mathrm{C}$. Samples were freeze-dried and ground to powder before stable isotope analyses.

On each sampling date, ophiuroid specimens (30 individuals of each species) were kept in filtered seawater using a flow-through system for $24 \mathrm{~h}$ to clear their stomachs. Animals from each location were maintained in separate tanks. A pool of 10 individuals (ca. $10 \mathrm{~mm}$ disk diameter) per replicate and 3 replicates per species were sampled, rinsed with filtered seawater, and frozen at $-80^{\circ} \mathrm{C}$. Each replicate was ground to powder with a Dangoumau homogenizer, and sub-sampled for stable isotope and fatty acid analyses. Sub-samples were stored at $-80^{\circ} \mathrm{C}$ before being analyzed. 


\section{Stable isotope analyses}

SPOM and TOM samples collected on GF filters were treated with $\mathrm{HCl}$ fumes $(10 \mathrm{~N})$ for $24 \mathrm{~h}$ to remove carbonates, and then dried at $40^{\circ} \mathrm{C}$ before $\delta^{13} \mathrm{C}$ analysis. SOM samples were decarbonated with $1 \mathrm{~N}$ $\mathrm{HCl}_{i}$ sub-samples of ground animal tissues were freeze-dried and also decarbonated with $1 \mathrm{~N} \mathrm{HCl}$. Lipids were removed using a cyclohexane solution (Kojadinovic et al. 2008). Lipid-free tissues were dried at $48^{\circ} \mathrm{C}$ for $24 \mathrm{~h}$ prior to acid treatment. Untreated samples were used for $\delta^{15} \mathrm{~N}$ analyses.

Isotopic analyses were performed with a Finnigan MAT Delta Plus isotope ratio mass spectrometer (IRMS) coupled with a Carlo Erba NC2500 elemental analyser in the Isotope Stable Laboratory at Cornell University, New York. The analytical error was $0.2 \%$ for both $\mathrm{N}$ and $\mathrm{C}$ (as measured with internal laboratory standards). Stable isotopic data are expressed as the relative per $\mathrm{ml}$ differences between the samples and the conventional standard Pee Dee Belemnite (PDB) for carbon and air $\mathrm{N}_{2}$ for nitrogen, according to the following equation:

$$
\delta X=\left[\left(R_{\text {sample }} / R_{\text {standard }}\right)-1\right] \times 1000
$$

where $X$ (in \%o) is the ${ }^{13} \mathrm{C}$ or ${ }^{15} \mathrm{~N}$ abundance and $R$ is the ${ }^{13} \mathrm{C} /{ }^{12} \mathrm{C}$ or ${ }^{15} \mathrm{~N} /{ }^{14} \mathrm{~N}$ ratio.

To interpret changes in stable isotopic compositions and to assess food source contributions in consumers' tissues, estimates of trophic discrimination factors (TDFs, hereafter denoted as $\Delta$ ) are of critical importance (DeNiro \& Epstein 1978, Minagawa \& Wada 1984). A previous feeding experiment showed that the TDF in Ophiothrix fragilis is lower than in Ophiocomina nigra, irrespective of food sources (Blanchet-Aurigny et al. 2012b). Therefore, isotopic compositions of $O$. fragilis were normalized with respect to those of $O$. nigra by adding +0.8 and $+0.5 \%$ respectively to the original $\delta^{13} \mathrm{C}$ and $\delta^{15} \mathrm{~N}$ values (Blanchet-Aurigny et al. 2012b). The food sources were also corrected using specific TDFs: TDFs for SPOM and SOM $\left(\Delta \delta^{13} \mathrm{C}=+2 \% ; \Delta \delta^{15} \mathrm{~N}=\right.$ $+3.6 \%$ ) were estimated via a feeding experiment with filter-feeding species using phytoplankton, which is the main component of these 2 food sources (Dubois et al. 2007a); TDFs for Ulva sp. $\left(\Delta \delta^{13} \mathrm{C}=\right.$ $-2.35 \% ; \Delta \delta^{15} \mathrm{~N}=+3.4 \%$ ) were calculated using a feeding experiment involving $O$. nigra and $O$. fragilis fed with fresh Ulva sp. The unexpected negative value of $\Delta \delta^{13} \mathrm{C}$ was due to the small amount of digestible material in this macroalgae (BlanchetAurigny et al. 2012b). After adjustment by trophic discrimination factors (fractionation factors), the diet of a given consumer was determined based on the close similarity of $\delta^{13} \mathrm{C}$ and $\delta^{15} \mathrm{~N}$ values between potential food sources and that given consumer.

\section{Lipid analyses}

Approximately $200 \mathrm{mg}$ of powdered animal samples per replicate ( 3 replicates per analysis) for each species was placed in glass vials filled with $3 \mathrm{ml}$ of dichloromethane-methanol $\left(\mathrm{CHCl}_{2}-\mathrm{MeOH}\right.$ mixture) $(2: 1 \mathrm{v} / \mathrm{v})$ prior to total lipid extraction following Folch et al. (1957). An aliquot of the lipid extract was evaporated to dryness and lipids were recovered with three $0.5 \mathrm{ml}$ washings with chloroform-methanol $\left(\mathrm{CHCl}_{3}-\mathrm{MeOH}\right.$ mixture) $(98: 2 \mathrm{v} / \mathrm{v})$. The lipids were placed at the top of silica gel microcolumn $(30 \times 5 \mathrm{~mm}$ internal diameter; Kiesegel Merk; 70 to $230 \mu \mathrm{m}$ meshi previously heated to $450^{\circ} \mathrm{C}$ and deactivated with $6 \%$ water). The neutral lipids were eluted with $10 \mathrm{ml} \mathrm{CHCl}_{3}-\mathrm{MeOH}$ mixture (98:2 v/v). The polar lipids were eluted with $15 \mathrm{ml}$ methanol. A known amount of 23:0 fatty acid was added as an internal standard to both neutral and polar fractions of the animal samples. Lipids were transesterified with 10 wt. \% boron trifluoride-methanol (Metcalfe \& Schmitz 1961) and analysed according to the method described by Marty et al. (1992); the fatty acid methyl esters were analyzed in a gas chromatograph with an on-column injector, a DB-Wax $(30 \mathrm{~m} \times 0.25 \mathrm{~mm}$; $0.25 \mu \mathrm{m}$ film thickness) capillary column and a flame ionization detector.

Fatty acids were identified by comparing their retention times with those of known standards: a 37 component fatty acid methyl ester (FAME) mix, bacterial acid methyl ester (BAME) mix and polyunsaturated fatty acid-PUFA No. 3 (from Menhaden oil) (Supelco). Because polar lipids are less sensitive to dietary changes (Lee et al. 1971), only fatty acid profiles of neutral lipids of both $O$. nigra and $O$. fragilis were included in this study. All fatty acids contributing to at least $0.5 \%$ of the total were taken into account. Table 1 shows a summary of the dietary fatty acid markers investigated in the present study.

\section{Statistical analyses}

A time series of fatty acids (mean of 3 replicates) for each species and sampling site $(B B, B S, D i, D o$, see Fig. 1) were associated using a hierarchical clustering method based on the Euclidian distance and Ward's linkage methods (Ward 1963). The clustering 
and related time series were represented using heat map plots of the raw dataset (Eisen et al. 1998). A heat map is a graphical representation of data where the values of a variable on a 2-dimensional map are represented by squares with colour gradients, and variables (here fatty acid compositions) are ordered according to the dendrogram defined by the hierarchical clustering. Each of the fatty acids contributing to at least $0.5 \%$ of the neutral lipids is represented on the heat map. The multivariate analysis and heat map were performed with $\mathrm{R}$ (R Development Core Team 2012).

In addition to multivariate analyses, factorial 3-way split-plot analyses of variance (ANOVAs) were conducted to determine differences in stable isotopes $\left(\delta^{13} \mathrm{C}\right.$ and $\left.\delta^{15} \mathrm{~N}\right)$ and selected fatty acid combinations according to species (fixed between-subjects factor with 2 levels: $O$. fragilis and $O$. nigra), locations (latitude, fixed between-subjects factor with 2 levels: north $[\mathrm{BB}+\mathrm{BS}]$ and south $[\mathrm{Di}+\mathrm{Do}] ;$ and exposure and terrestrial inputs, fixed between-subjects factor with 2 levels: Inshore [BB + Di] and offshore [BS + Do], and their interactions), sampling dates (random factor with 5 levels of repeated measurements: June 2010, August 2010, October 2010, January 2011, April 2011) and their mutual interactions (see Table 2). Significant differences between all possible combinations of sample means were assessed using least-square means multiple comparisons tests $(p<$ 0.05). Homogeneity of variance-covariance matrices were graphically assessed. All ANOVAs were performed with SAS 9.0 (SAS Institute).
The package Stable Isotope Bayesian Ellipses in $\mathrm{R}$ (SIBER) (R Development Core Team 2012) was used to investigate the overall variability (including all sites and dates) in isotopic values for each ophiuroid population. In this study, 2 metrics were applied: (1) the total area (TA), calculated from a convex hull drawn around the most extreme data points in a $\delta^{13} \mathrm{C}$ versus $\delta^{15} \mathrm{~N}$ biplot, which emphasized the overall dispersion of individuals' diets within the trophic niche proxied by the isotopic space; and (2) the standard ellipses area (SEAc), calculated as a measure of the mean core population isotopic niche. SEAc is designed to cope with differences in sampling efforts (none here) and to provide a statistical background to facilitate comparisons since it is based on the variability in isotopic compositions (Jackson et al. 2011, Brind'Amour \& Dubois 2013). These 2 metrics were used as a quantitative proxy of the overall annual diversity in trophic niches of the 2 co-occurring species (Layman et al. 2012): high metric values would be linked to a larger diversity in trophic sources and/or a larger plasticity. The TA or SEAc in a $\delta$-space could then be seen as a proxy for the trophic niche of the ophiuroids, and overlap in TA or SEAc would indicate potential direct inter-specific competition.

Finally, relationships between (1) $\delta^{15} \mathrm{~N}$ and the ratio of the fatty acids $18: 1 \mathrm{n}-9$ to $18: 1 \mathrm{n}-7$ (omnivory index), and (2) the fatty acids trans-16:1n-13 and bacterial markers (iso and anteiso 15:0 + 17:0) were estimated to provide a more accurate depiction of the spatiotemporal variability among ophiuroids, specifically re-

Table 1. Dietary fatty acid markers discussed in this study

\begin{tabular}{|c|c|c|}
\hline Marker & Diet & Source \\
\hline $20: 5 n-3 / 22: 6 n-3$ & Diatoms to flagellates & Budge \& Parrish (1998) \\
\hline $16: 4 n-1$ & Diatoms & Dalsgaard et al. (2003) \\
\hline $16: 1 \mathrm{n}-7 / 16: 0$ & Diatoms & \\
\hline $15: 0+17: 0^{\mathrm{a}}$ & Bacteria & Volkman et al. (1980) \\
\hline PUFA/SFA ${ }^{\mathrm{b}}$ & Phytoplankton vs. detritus & $\begin{array}{l}\text { Biandolino et al. (2008), Pommier et al. (2010), Maazouzi et al. } \\
\text { (2007), Prato et al. (2012) }\end{array}$ \\
\hline \multirow[t]{3}{*}{ Trans-16:1n-13 } & Higher plants & Nichols et al. (1982) \\
\hline & Green macroalgae & Nelson et al. (2002) \\
\hline & Phytoplankton & Dunstan et al. (1992), Terasaki et al. (2002), Veloza et al. (2006) \\
\hline \multirow[t]{2}{*}{$18: 2 n-6+18: 3 n-3$} & Terrestrial vascular plants & Dalsgaard et al. (2003) \\
\hline & Green macroalgae & Kelly \& Scheibling (2012), Khotimchenko et al. (2002) \\
\hline $18: 1 n-9 / 18: 1 n-7$ & Omnivory & $\begin{array}{l}\text { Auel et al. (2002), Stevens et al. (2004), Graeve et al. (1997), } \\
\text { El-Sabaawi et al. (2009, 2010) }\end{array}$ \\
\hline $20: 1$ and $22: 1$ isomers $^{\mathrm{c}}$ & Copepods & $\begin{array}{l}\text { Ackman et al. (1980), Budge et al. (2002), Sargent \& Whittle } \\
\text { (1981), Kattner et al. (2012) }\end{array}$ \\
\hline \multicolumn{3}{|c|}{ ancludes iso and anteiso branched chains containing 15 to 17 carbon atoms } \\
\hline \multicolumn{3}{|c|}{ 'Includes monounsaturated fatty acids containing 20 or 22 carbon atoms $(20: 1 n-11,20: 1 n-9,22: 1 n-9)$} \\
\hline
\end{tabular}


IN
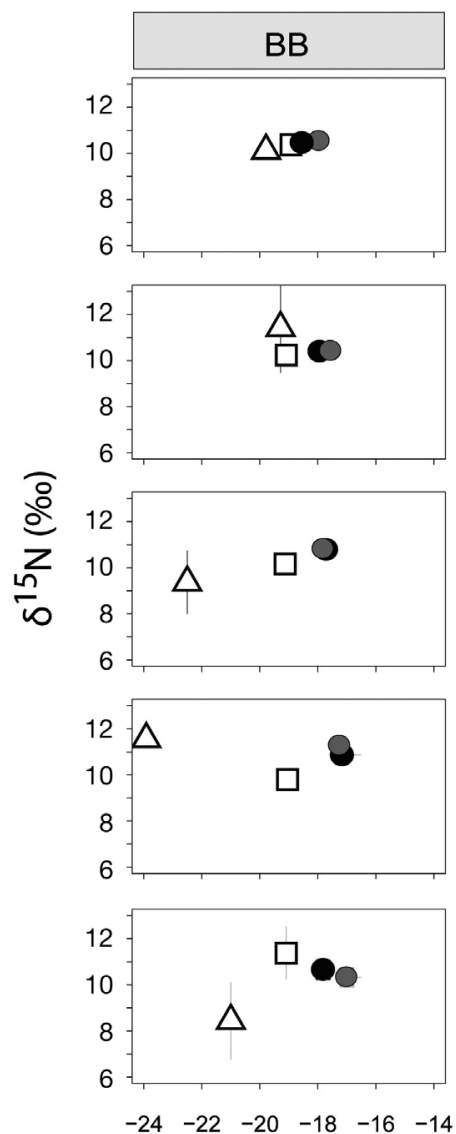

$\begin{array}{llllllllllll}-24 & -22 & -20 & -18 & -16 & -14 & -24 & -22 & -20 & -18 & -16 & -14\end{array}$

Consumers

O. fragilis

- O. nigra
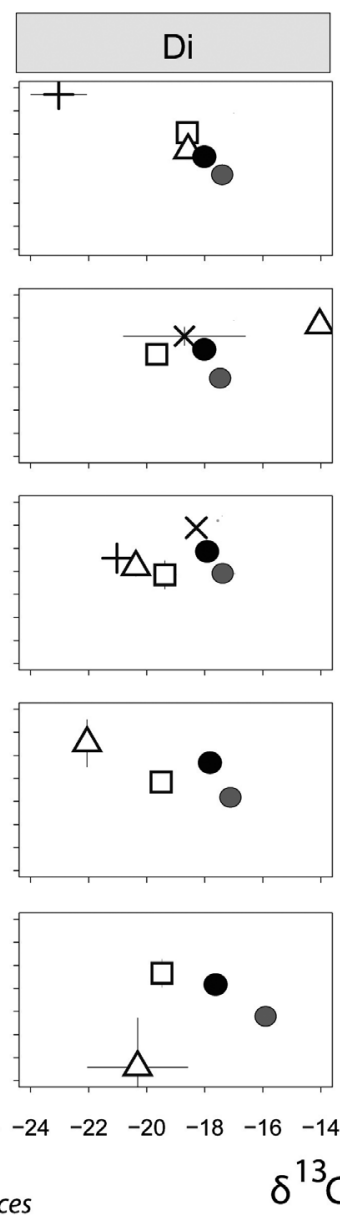

Food sources

$\triangle$ SPOM $\square$ SOM

+ Ulva sp. in water column $\delta^{13} \mathrm{C}(\%)$
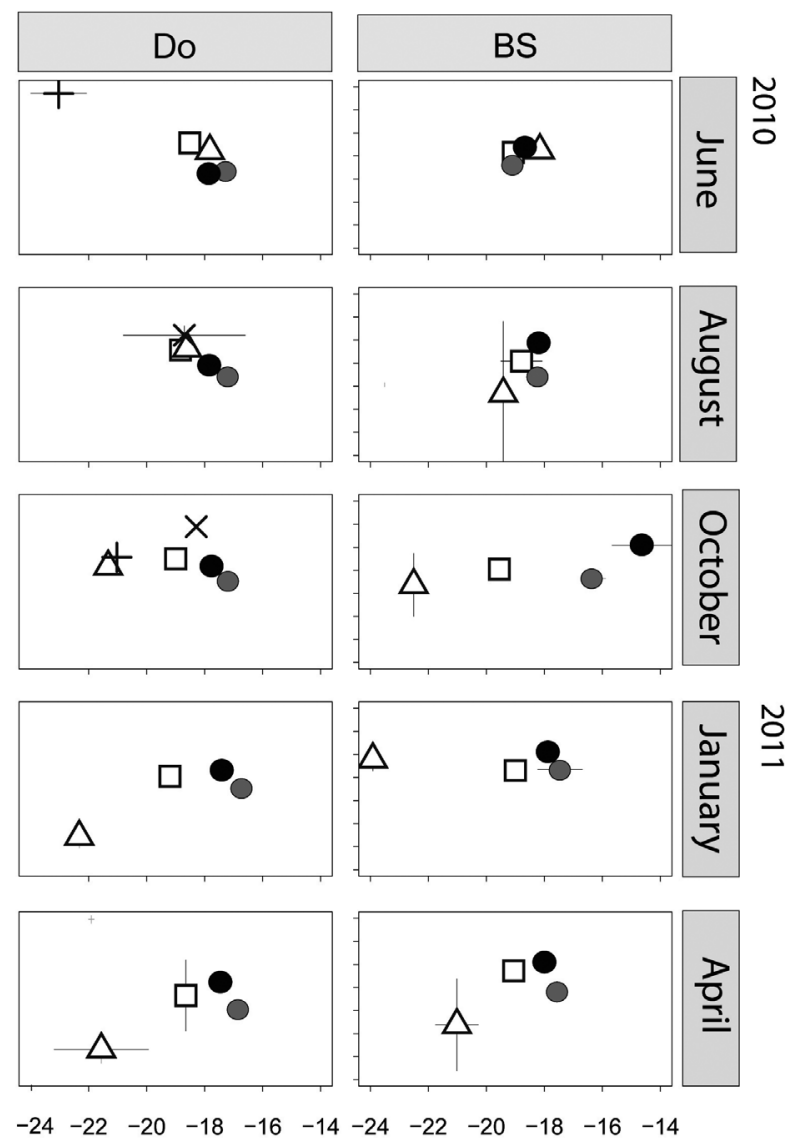

Fig. 2. $\delta^{15} \mathrm{~N}$ and $\delta^{13} \mathrm{C}$ in Ophiocomina nigra and Ophiothrix fragilis tissues (whole animal) and in their food sources-suspended organic matter (SPOM), sedimented organic matter (SOM), and Ulva sp. — by sites (Bay of Douarnenez inshore [Di] and offshore [Do], Bay of Brest [BB] and Blanc-Sablons [BS]), sampling dates and exposure (IN and OUT). Error bars are SD

garding their relative trophic positions and their relative consumption of plant detritus. The relationships were investigated by calculating the Pearson's correlation coefficients (r) (R Development Core Team 2012).

\section{RESULTS}

\section{Stables isotopes of food sources and ophiuroids}

Stable isotope values of potential food sources and both ophiuroid species are presented in Table S1 in the Supplement at www.int-res.com/articles/suppl/ m525p127_supp.pdf. The biplots $\left(\delta^{13} \mathrm{C}\right.$ and $\left.\delta^{15} \mathrm{~N}\right)$ of isotopic compositions of organic food sources (cor- rected for trophic discrimination) and both ophiuroids are presented in Fig. 2.

Isotopic signatures of the food sources (SPOM, SOM, TOM and Ulva sp.) varied according to location and time. Temporal variations in $\delta^{13} \mathrm{C}$ in SPOM were similar between locations. In contrast, location and time seemed to interact in their effects on $\delta^{15} \mathrm{~N}$ in SPOM. In contrast to SPOM, $\delta^{13} \mathrm{C}$ and $\delta^{15} \mathrm{~N}$ values in SOM were fairly constant irrespective of location and time. Similarly, $\delta^{13} \mathrm{C}$ values of TOM remained relatively constant over time, although were severely depleted compared to SPOM. However, $\delta^{15} \mathrm{~N}$ values of TOM varied markedly with time (Table S1). Values of $\delta^{13} \mathrm{C}$ and $\delta^{15} \mathrm{~N}$ in stranded samples of Ulva sp. (Di and Do) were similar to those of floating specimen 
collected on 10 August. However, some changes were observed in the 10 October sample, where values of $\delta^{13} \mathrm{C}$ and $\delta^{15} \mathrm{~N}$ in stranded algae were more enriched than those of floating Ulva sp. (Table S1, Fig. 2).

Among the 4 potential food sources (SPOM, SOM TOM and Ulva sp.), only SPOM, SOM, and Ulva sp. likely contributed to the ophiuroid diets. Moreover, the contributions of these food sources varied slightly as a function of species, location and sampling time. On 10 June and 10 August, both ophiuroid species relied on SPOM and SOM overall, regardless of location. From 10 October to 11 April, SOM likely contributed more than SPOM to the diet of the ophiuroids. However in BS on 10 October, and in Di only for $O$. fragilis from January to 11 April, both species were far away from sampled food sources. From August to 10 October in the southern areas (Do and Di), Ulva sp. contributed more to the $\operatorname{diet}$ of $O$. nigra than $O$. fragilis (Fig. 2).

The 2 ophiuroid species showed distinct stable isotope signature: values of $\delta^{15} \mathrm{~N}$ in $O$. fragilis were generally lower than those observed in O. nigra, whereas values of $\delta^{13} \mathrm{C}$ overlapped between the 2 species (Fig. 3). Values of $\delta^{13} \mathrm{C}$ generally ranged between -17.6 and $-18.6 \%$ for $O$. nigra, and between -16.6 and $-19.6 \%$ for $O$. fragilis. Isotopic metrics revealed little overlap between the 2 ophiuroids (only the convex hull areas overlapped). O. nigra occupied a smaller isotopic niche space $(\mathrm{SEAc}=0.49, \mathrm{TA}=1.50)$ than $O$. fragilis $(\mathrm{SEAC}=1.32, \mathrm{TA}=3.70)$. The $\delta^{13} \mathrm{C}$ and $\delta^{15} \mathrm{~N}$ ranges were both larger for $O$. fragilis (Fig. 3).

\section{Fatty acid compositions of ophiuroids}

Fatty acid compositions of neutral lipids in soft tissues of $O$. fragilis and $O$. nigra are presented in Table S2 in the Supplement, and summarized using a heat map (Fig. 4). Two clusters (I and III) of fatty acids appeared, distinctly and clearly separating the 2 ophiuroids (Fig. 4). The first cluster consisted of fatty acids characteristic of $O$. nigra, namely 14:0, 16:0, 20:1n-11, 16:1n-7, 24:6n-3, 16:4n-3, 22:1n-9, 18:1n-9, 22:6n-3, non-methylene interrupted (NMI) fatty acids (20:2 and 22:2), bacterial fatty acids, and trans-16:1n13. The second cluster consisted of fatty acids that occurred in similar proportions in both ophiuroids, namely 18:3n-3, 18:2n-6, 16:3n-6, 18:0, 20:4n-6, 16:3n-3. Finally, the third cluster consisted of fatty acids which occurred in higher proportions in $O$. fragilis, and included 20:5n-3, 16:4n-1, 18:4n-3, 18:1n-7 and 18:1n-11 (Fig. 4).

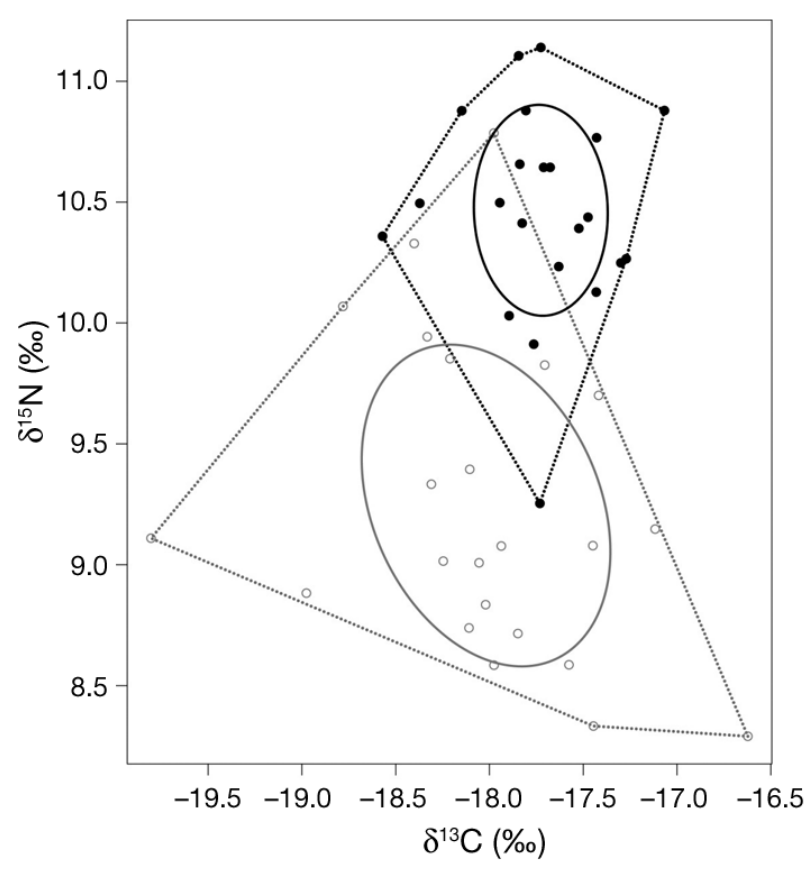

Fig. 3. Population isotope niche widths of both ophiuroids (all sites and all dates). Standard ellipses areas (SEAc, solid lines) and total area from convex hull (TA, dotted lines) estimations for Ophiocomina nigra (black spots and lines) and Ophiothrix fragilis (grey spots and lines) populations using Stable Isotope Bayesian Ellipses in R (SIBER) (Jackson et al. 2011)

Although ophiuroid species, location and sampling date effects on 16:1n-7/16:0 interacted (species $\times$ latitude $\times$ exposure $\times$ time; $\mathrm{p}<0.0001$, Table 2 ), this diatom marker varied only slightly (from 0.63 to 0.93 , except in $O$. nigra collected at $\mathrm{BS}$, where values higher than 1.0 were recorded) and no clear spatiotemporal pattern emerged (Fig. 5A). As observed for 16:1n-7/16:0, species, location and sampling date effects on 20:5n-3/22:6n-3 interacted ( $<<0.0001$; Table 2, Fig. 5B). However, this diatom marker was 3 to 6 times higher in $O$. fragilis than observed in $O$. nigra, irrespective of location or sampling date $(p<0.001)$. It is also noteworthy that values of 20:5n3/22:6n-3 were particularly high in both ophiurid species, ranging from 15.5 to 58.4 in $O$. fragilis and from 3.6 to 21.7 in $O$. nigra, reflecting low levels of 22:6n-3 (see Table S2). In O. nigra, values of 20:5n3/22:6n-3 increased by 2 and 6 times from 10 October onward at Do and $\mathrm{Di}$, respectively, whereas they remained fairly constant at BB and BS. In O. fragilis, values of 20:5n-3/22:6n-3 increased from 10 October onward at Di and Do as observed in O. nigra; however, at BB and BS, ratio values in $O$. fragilis peaked on 11 January, reaching 58.4 and 46.9, respectively. 


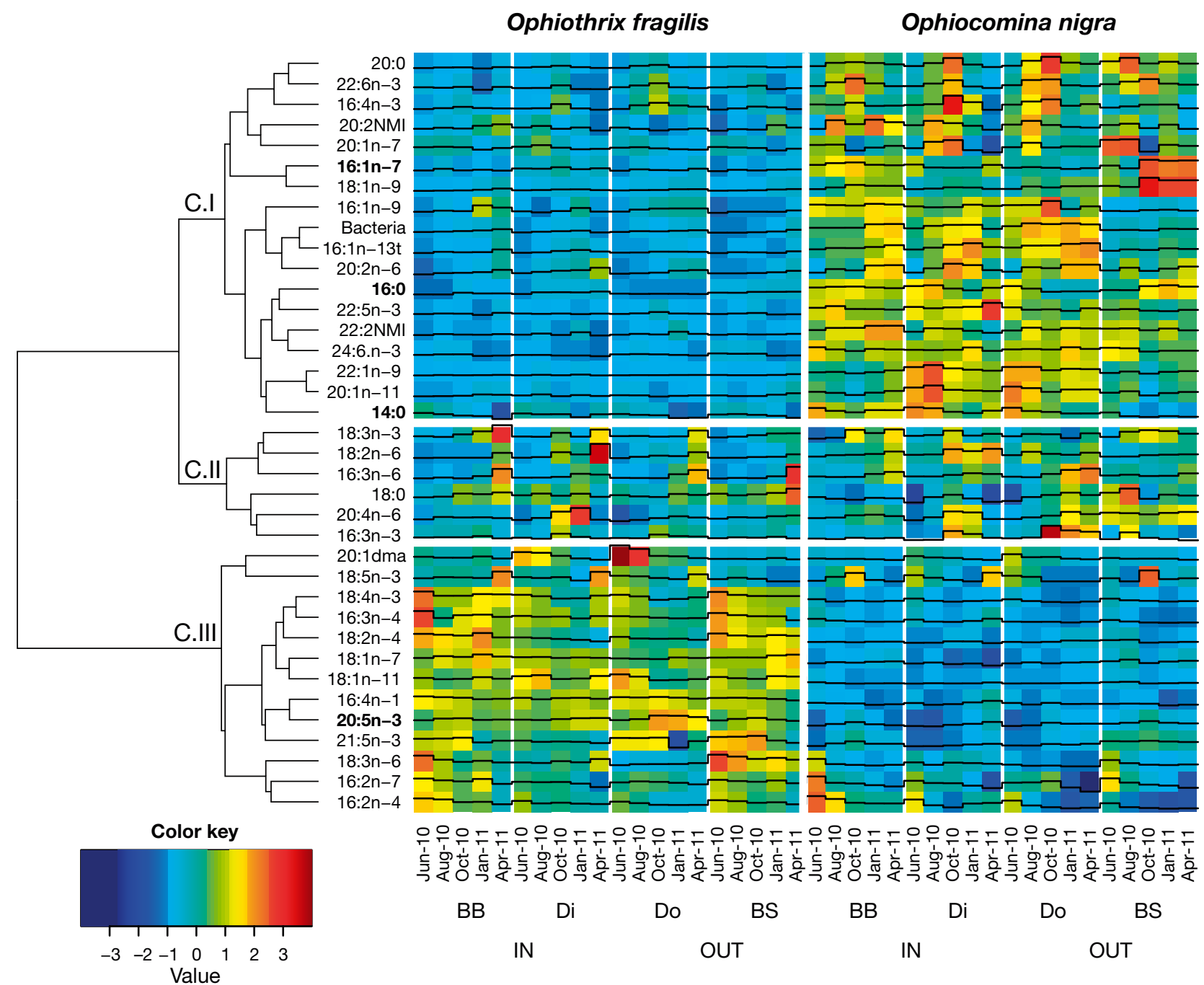

Fig. 4. Heat map plots showing time-series of fatty acids contributing $>0.5 \%$ mass of total fatty acids in Ophiothrix fragilis and Ophiocomina nigra, averaged by sampling dates, sites (BB: Bay of Brest; Di and Do: inshore and offshore zones of Bay of Douarnenez; BS: Blanc-Sablons) and exposure (IN versus OUT). Fatty acids were reordered according to the hierarchical clustering result given by the dendrogram. The horizontal white lines separate the 3 clusters (C.I, C.II, C.III) of fatty acids. The vertical white lines separate the sampling sites and species. Fatty acids in bold are dominant. Bacteria include the sum of iso and anteiso branched chains containing 15-17 carbon atoms; NMI: Non-Methylene_Interrupted; t: Trans; dma: total of dimethyl acetals

The polyunsaturated/saturated (PUFA/SFA) ratio was about 2 times higher for $O$. fragilis than $O$. nigra $(p<0.0001$; Table 2, Fig. 5C) regardless of location and sampling date, and remained at that level over time for both species.

Values of $18: 2 n-6+18: 3 n-3$ ranged from 0.7 to $1.9 \%$. There was a significant interaction of species, location and sampling date effects on this indicator ( $p<0.0001$; Table 2, Fig. 5D). These values were generally higher in $O$. nigra compared to those observed in $O$. fragilis, and remained fairly constant at Do, whereas they increased regularly at BB and BS, and chaotically at Di. Values of 18:2n-6 + 18:3n-3 recorded at the end of the study period showed a $32 \%$ increase inside the bays ( $\mathrm{BB}$ and $\mathrm{Di}$, mean $=1.55 \%$ ) compared to those observed outside (BS and Do, mean $=1.18 \%$ ), irrespective of ophiuroid species.

The sum of iso- and anteiso-branched chain fatty acids and unbranched 15:0 and 17:0 varied as a function of the interaction among species, location and sampling date ( $\mathrm{p}<0.0001$; Table 2, Fig. 5E). Overall, values for this bacterial marker were lower in $O$. fragilis (between 0.8 and 1.9\%) than in O. nigra, in which they ranged from 1.6 to $3.2 \%$. For O. nigra, these values increased gradually between 10 June and 11 January at BB and Di to reach $3.2 \%$. At Do, bacterial fatty acids were initially higher than that observed at BB and Di ( $p<0.001$, Fig. 5E) and 
Table 2. Factorial 3-way repeated measure ANOVA results for the effect of latitude (north: BB + BS versus south: Di + Do), region (inshore: BB + Di versus offshore: BS +Do), species (Ophiocomina nigra versus Ophiothrix fragilis), and date of sampling (5 sampling dates) on stable isotopes and selected fatty acid dietary markers (ratio and/or sum of fatty acids). See Fig. 1 for location abbreviations. Bacteria: sum of iso and anteiso branched chain fatty acids. ${ }^{*} \mathrm{p}<0.05(\mathrm{n}=3)$; rep: replicate

\begin{tabular}{|c|c|c|c|c|c|c|c|c|c|}
\hline Source of variation & $\delta^{13} \mathrm{C}$ & $\delta^{15} \mathrm{~N}$ & $\begin{array}{c}16: 1 \mathrm{n}-7 / \\
16: 0\end{array}$ & $\begin{array}{l}20: 5 n-3 / \\
22: 6 n-3\end{array}$ & $\begin{array}{l}\text { ¿PUFA/ } \\
\sum \text { SFA }\end{array}$ & $\begin{array}{l}18: 2 n-6 \\
+18: 3 n-3\end{array}$ & Bacteria & $20: 1 n-11$ & $\begin{array}{l}18: 1 \mathrm{n}-9 / \\
18: 1 \mathrm{n}-7\end{array}$ \\
\hline \multicolumn{10}{|l|}{ Between-subjects } \\
\hline Species & $<0.0001^{*}$ & $<0.0001^{*}$ & $0.0013^{*}$ & $<0.0001^{*}$ & $<0.0001^{*}$ & $<0.0001^{*}$ & $<0.0001^{*}$ & $<0.0001^{*}$ & $<0.0001^{*}$ \\
\hline Region & 0.3712 & $<0.0001^{*}$ & 0.0729 & $<0.0001^{*}$ & $0.0012^{*}$ & $<0.0001^{*}$ & $0.0057^{*}$ & 0.3422 & $0.0013^{*}$ \\
\hline Latitude & $0.0053^{*}$ & $<0.0001^{*}$ & $0.0007^{*}$ & $0.0481^{*}$ & 0.2299 & $<0.0001^{*}$ & $<0.0001^{*}$ & $<0.0001^{*}$ & $0.0026^{*}$ \\
\hline Region $\times$ Latitude & 0.6205 & $0.0236^{*}$ & 0.2436 & $0.0002^{*}$ & $0.0005^{*}$ & $0.0007^{*}$ & $<0.0001^{*}$ & 0.0641 & $0.0142^{*}$ \\
\hline Region $\times$ Species & $0.0010^{*}$ & $0.0032^{*}$ & $0.0083^{*}$ & $<0.0001^{*}$ & 0.1517 & 0.1935 & 0.0835 & 0.2804 & $0.0015^{*}$ \\
\hline Latitude $\times$ Species & $<0.0001^{*}$ & $0.0039^{*}$ & $<0.0001^{*}$ & 0.4436 & 0.2542 & 0.2875 & $<0.0001^{*}$ & $<0.0001^{*}$ & $0.0004^{*}$ \\
\hline Region $\times$ Latitude $\times$ Species & 0.0687 & $<0.0001^{*}$ & 0.0663 & 0.3350 & $0.0001^{*}$ & 0.4154 & $<0.0001^{*}$ & 0.2081 & $0.0075^{*}$ \\
\hline \multicolumn{10}{|c|}{ Error $\mathrm{a}=\operatorname{rep}($ Region $\times$ Latitude $)$} \\
\hline \multicolumn{10}{|l|}{ Within-subjects } \\
\hline Date & $<0.0001^{*}$ & $<0.0001^{*}$ & $0.0140^{*}$ & $<0.0001^{*}$ & $<0.0001^{*}$ & $<0.0001^{*}$ & $<0.0001^{*}$ & $<0.0001^{*}$ & $<0.0001^{*}$ \\
\hline Region $\times$ Date & $<0.0001^{*}$ & $<0.0001^{*}$ & $0.0003^{*}$ & $<0.0001^{*}$ & $0.0005^{*}$ & $<0.0001^{*}$ & $<0.0001^{*}$ & $0.0102^{*}$ & 0.2037 \\
\hline Latitude $\times$ Date & $<0.0001^{*}$ & $<0.0001^{*}$ & 0.3133 & $<0.0001^{*}$ & $<0.0001^{*}$ & $<0.0001^{*}$ & $<0.0001^{*}$ & $<0.0001^{*}$ & $0.0005^{*}$ \\
\hline Species $\times$ Date & $<0.0001^{*}$ & $<0.0001^{*}$ & $<0.0001^{*}$ & $<0.0001^{*}$ & 0.0812 & $<0.0001^{*}$ & $<0.0001^{*}$ & $<0.0001^{*}$ & $<0.0001^{*}$ \\
\hline Region $\times$ Species $\times$ Date & $0.0208^{*}$ & 0.0795 & 0.1090 & $<0.0001^{*}$ & $0.0299^{*}$ & $<0.0001^{*}$ & 0.0654 & 0.2844 & 0.1305 \\
\hline Latitude $\times$ Species $\times$ Date & $0.0092^{*}$ & $0.0007^{*}$ & $0.0081^{*}$ & $<0.0001^{*}$ & 0.1098 & $<0.0001^{*}$ & $<0.0001^{*}$ & 0.1717 & $0.0002^{*}$ \\
\hline $\begin{array}{l}\text { Region } \times \text { Latitude } \times \\
\text { Species } \times \text { Date }\end{array}$ & $<0.0001^{*}$ & 0.1134 & $<0.0001^{*}$ & $<0.0001^{*}$ & $0.0023^{*}$ & $<0.0001^{*}$ & $<0.0001^{*}$ & $<0.0001^{*}$ & $0.0002^{*}$ \\
\hline \multicolumn{10}{|c|}{ Error $b=$ Species $\times$ rep $($ Region $\times$ Latitude $)$} \\
\hline
\end{tabular}

remained fairly stable. In both species, values of this bacterial marker remained fairly constant in BS. The fatty acid trans-16:1n-13 was positively correlated with bacterial fatty acids $(\mathrm{p}<0.001$, Pearson's $\mathrm{r}=$ 0.93). Again, specimens belonging to O. nigra were on the top right and corner of the biplot, while $O$. fragilis specimens were on the bottom left hand corner (Fig. 6). The highest values of bacterial and trans16:1n-13 fatty acids were observed in Di and Do for O. nigra.

Values of 20:1n-11 varied as a function of the interaction among species, location and sampling date ( $p<0.0001$, Table 2$)$. The levels of this fatty acid varied from 3.8 to $13 \%$ for $O$. nigra as a function of location and time, whereas those of $O$. fragilis remained relatively constant over time $(\sim 4 \%)$ irrespective of location. At Di and Do, the level of 20:1n-11 was 2 times higher in $O$. nigra than in $O$. fragilis and approximately 3 times higher in June and August 2010 (Fig. 5F). Although values of 18:1n-9/18:1n-7 varied as a function of the interaction among species, location and sampling date $(\mathrm{p}=0.0002$, Table 2$)$, values observed in $O$. nigra were 3 times higher than those in $O$. fragilis, regardless of location or sampling date (Fig. 5G). Temporal variations in 18:1n-9/18:1n7 were rather low, except for $O$. nigra collected at BS, where the values increased by 3 times between 10 August and 10 October. Interestingly, 18:1n-9/18:1n-
7 increased with increasing $\delta^{15} \mathrm{~N}$ in the ophiuroids $(\mathrm{p}<0.0001$, Pearson's $\mathrm{r}=0.70)$. Moreover, all specimens of $O$. nigra were distributed on the top right and corner of the biplot while $O$. fragilis specimens were on the bottom left hand corner (Fig. 7). Note that no relationship between $18: 1 n-9 / 18: 1 n-7$ and $\delta^{15} \mathrm{~N}$ occurred for $O$. fragilis in BB.

\section{DISCUSSION}

The present study investigated the trophic niches of 2 co-occurring ophiuroid species, Ophiocomina nigra and Ophiothrix fragilis, at 4 locations in Brittany (France) over a 1 yr period, by means of stable isotope and fatty acid analyses. Our study provides evidence that although these species could potentially compete for similar food resources, they are segregated as a result of using different feeding strategies, leading to differences in their trophic niche.

\section{Trophic relationships between ophiuroid species}

The relationship between $\delta^{15} \mathrm{~N}$ and 18:1n-9/18:1n-7 revealed differences in relative trophic positions between ophiuroid species which can be used to dis- 

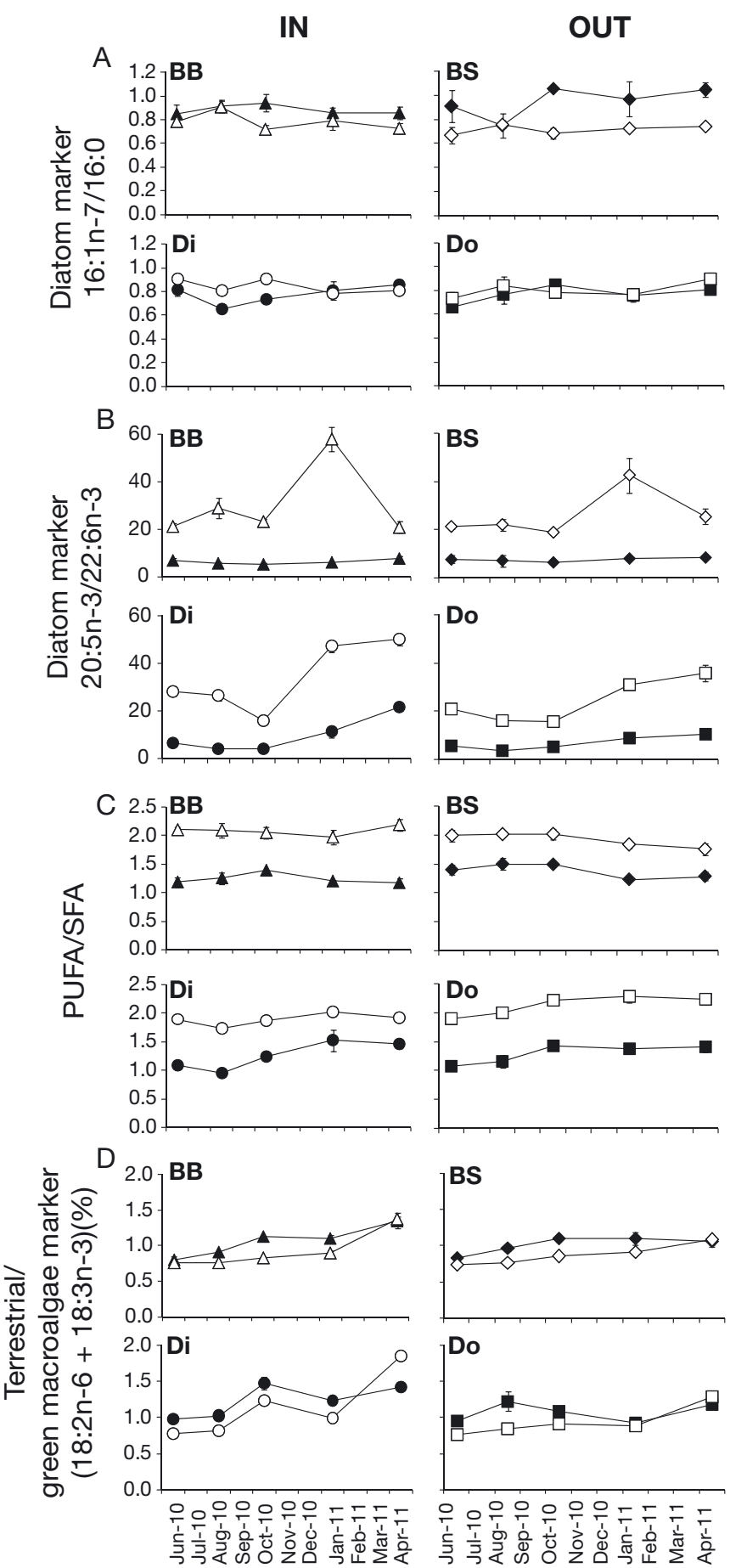

BS

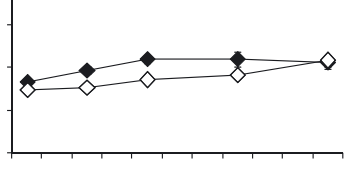

Do

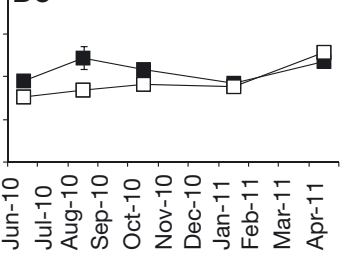

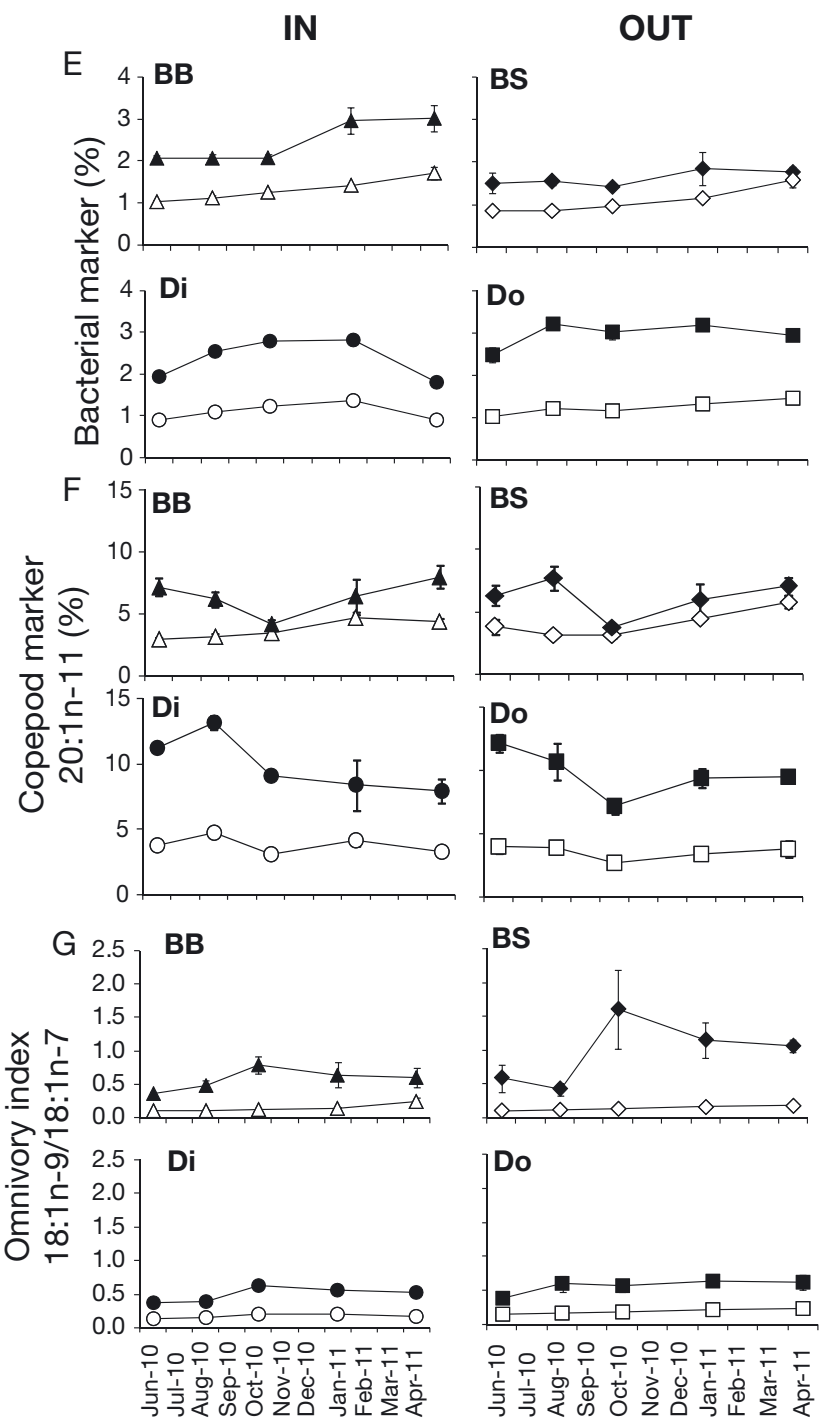

Fig. 5. Temporal variation in fatty acids (mean $\pm \mathrm{SD}$ ) used as trophic markers in Ophiocomina nigra (black symbols) and Ophiothrix fragilis (white symbols) by sampling sites (Bay of Brest [BB, triangle]; Blanc-Sablons [BS, diamond]; Bay of Douarnenez inshore [Di, circle], offshore [Do, square]) and exposure (IN versus OUT). (A,B) Diatom markers (16:1n-7/16:0 and 20:5n-3/22:6n-3); (C) polyunsaturated/saturated fatty acid ratio (PUFA/SFA); (D) terrestrial and/or green macroalgae marker (sum of 18:2n-6 and 18:3n-3); (E) bacterial marker (sum of iso and anteiso branched chain fatty acid); (F) copepod marker $(20: 1 n-11) ;(G)$ omnivory index $(18: 1 n-9 / 18: 1 n-7)$

stable isotope and fatty acid analyses both corroborated the idea that this ophiuroid is more generally an opportunistic feeder. This feeding behaviour has been reported for many other ophiuroids (Warner 1982). Based on observations of stomach contents as well as tooth morphology (Warner \& Woodley 1975), $O$. fragilis is also capable of scavenging and preda-

tion (Boos 2012). However, our results suggested that a suspension-feeding species (Aronson 1989), but

tinguish patterns of trophic differentiation. Higher values of $\delta^{15} \mathrm{~N}$ in $O$. nigra compared to O. fragilis suggests that $O$. nigra occupies a higher trophic position. This was corroborated by the fact that values of 18:1n-9/18:1n-7, which reflect an omnivorous feeding mode, were markedly higher in O. nigra, and correlate positively with $\delta^{15} \mathrm{~N}$. O nigra is reported to be 


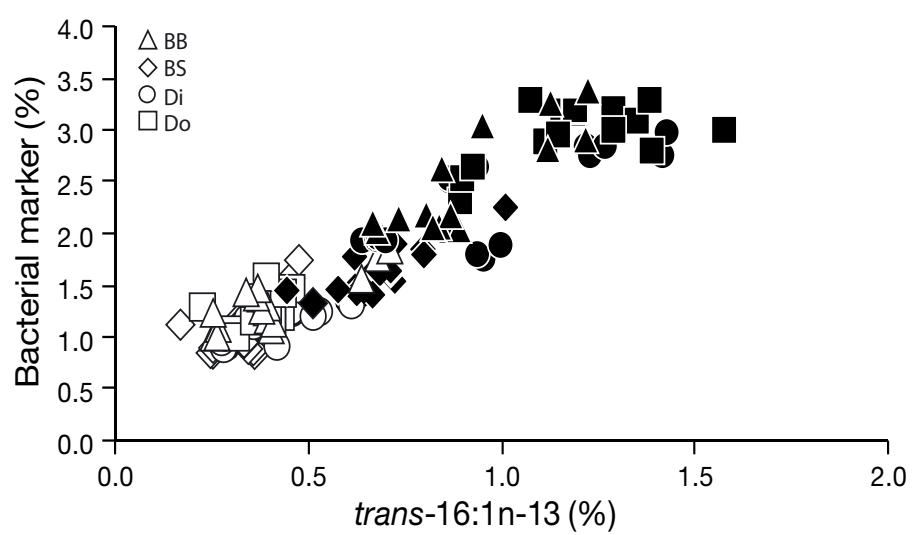

Fig. 6. Relationship between trans-16:1n-13 and bacterial markers in both Ophiocomina nigra (black) and Ophiothrix fragilis (white) by site: Bay of Douarnenez inshore (Di) and offshore (Do), Bay of Brest (BB) and Blanc-Sablons (BS). (Pearson's $r=0.93, p<0.0001$ )

assimilation of animal prey by $O$. fragilis is of minor importance. Values of 18:1n-9/18:1n-7 were consistent with those reported for the ophiuroids Ophiura sarsi and Ophiacantha borealis, which are considered to be carnivorous (ratio $=1.4$ ) and suspension feeders (ratio $=0.1$ ), respectively (Graeve et al. 1997).

In the present study, $O$. nigra exhibited high levels of 20:1n-11, likely reflecting the contribution of copepods to the diet, which could be ingested either along with detritus from the sediment or by active hunting (Ratnayake \& Ackman 1979, Drazen et al. 2008, Würzberg et al. 2011). However, levels of 20:1n-11 did not show a consistent rise with increasing levels of $18: 1 \mathrm{n}-9 / 18: 1 \mathrm{n}-9$ and $\delta^{15} \mathrm{~N}$. It is therefore possible that ophiuroids synthesize these monounsaturated isomers de novo (Drazen et al. 2008).

The ratios of 20:5n-3/22:6n-3, together with the fatty acids $16: 4 \mathrm{n}-1$ and $16: 3 \mathrm{n}-4$, were consistently higher in $O$. fragilis than in $O$. nigra. Therefore, it appears that $O$. nigra relies less on diatoms than $O$. fragilis, irrespective of location or sampling time. However, ratios of 20:5n-3/22:6n-3 were unusually high (>20) compared to values reported in the literature (Dalsgaard et al. 2003). It was previously reported that levels of 22:6n-3 are low in several ophiuroid species (including $O$. nigra and $O$. fragilis), because this fatty acid would have been elongated to 24:6n-3 (Takagi et al. 1986, McKenzie et al. 2000, Drazen et al. 2008). Thus, the species-specific differences in the ratios of 20:5n-3/22:6n-3 in our study may not reflect differences in food sources, but rather mirror the selective incorporation and elongation processes of fatty acids according to species-specific physiological requirements.

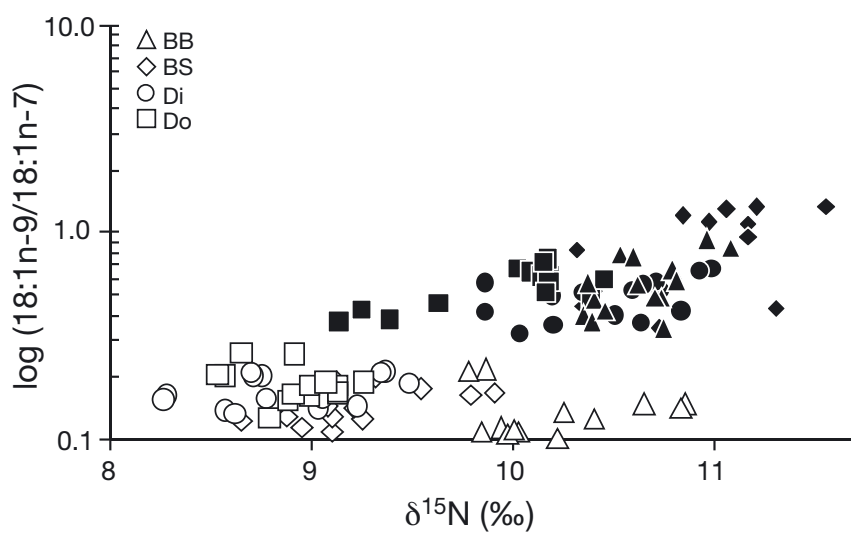

Fig. 7. Ratio of 18:1n-9/18:1n-7 (log transformed) versus $\delta^{15} \mathrm{~N}$ in both Ophiocomina nigra (black) and Ophiothrix fragilis (white) by site: Bay of Douarnenez inshore (Di) and offshore (Do), Bay of Brest (BB) and Blanc-Sablons (BS). (Pearson's $r=0.70, p<0.0001)$

Values of PUFA/SFA, an indication of the relative importance of phytoplankton versus detritus (Maazouzi et al. 2007, Biandolino et al. 2008, Pommier et al. 2010, Prato et al. 2012), were lower in O. nigra than in $O$. fragilis. However, bacterial fatty acids were higher in $O$. nigra than in $O$. fragilis. These results suggest that $O$. nigra relies less on diatoms and more on detritic organic matter and bacteria than O. fragilis. Additionally, O. nigra exhibited nonnegligible levels of trans-16:1n-13, which correlated positively with bacterial fatty acids. Considering that trans-16:1n-13 is a marker for phytodetritus, which could be derived from green algae, these results would imply that $O$. nigra grazed on microbial material (see references in Table 1 ). This result is also supported by higher levels of 18:2n-6 and 18:3n-3 in $O$. nigra, which can be used as a macroalgal signal when terrestrial inputs are absent or limited (Kelly \& Scheibling 2012).

Stable isotopes alone revealed that dietary overlap (TA and SEAc) between the 2 ophiuroid species was very limited and trophic separation was mainly detectable according to their $\delta^{15} \mathrm{~N}$ values. Thus, as previously suggested for other coexisting ophiuroid species (Iken et al. 2001), O. nigra and O. fragilis maintained some degree of trophic niche separation by differences in selective ingestion and feeding strategies. When organic matter consists of mixed sources, inter-specific differences in particle capture strategies may reduce competition among ophiuroids, as previously investigated for suspensionfeeder trophic niches (Dubois et al. 2007b,c, Lefebvre et al. 2009, Pernet et al. 2012, Dubois \& Colombo 2014). While both adult ophiuroid species are re- 
ported to be suspension-feeders, collecting particles from the water-column with their arms (Aronson 1989), O. nigra exhibits a much wider trophic plasticity and more versatile feeding behavior (Fontaine 1965).

Unexpectedly, $O$. nigra exhibited a somewhat lower overall annual variability in isotopic signatures than $O$. fragilis. We hypothesized that since the population of $O$. nigra assimilated a broad range of food sources with no marked dietary changes regardless of season or location, its isotope signature variability could be buffered.

\section{Spatio-temporal variations in stable isotope and fatty acid profiles of ophiuroids}

In our study, spatial and temporal variations in stable isotopes and fatty acid profiles of ophiuroids were generally low compared to inter-specific differences. This result was somewhat unexpected since these systems (the Bay of Brest and Bay of Douarnenez) differ in terms of their hydrodynamic patterns (e.g. depth, residency time and water currents), and both open sea off-shore stations are very different from their respective coastal and highly productive inshore stations. Sites located inside the bays exhibit frequent green macroalgae blooms (Ménesguen et al. 2006), predominantly in the inshore zone of the Bay of Douarnenez (e.g. up to $14000 \mathrm{t}$ of fresh spindried Ulva spp. recorded in 2009; CEVA 2011). The Bay of Brest is much more influenced by freshwater inputs rich in nitrates than the inshore zone of the Bay of Douarnenez, but is less susceptible to eutrophication due to favourable hydrodynamic conditions.

Stable isotope and fatty acid results were both consistent with a diet that is phytoplankton-oriented in summer, indicating that both ophiuroids feed on SPOM and/or SOM regardless of location. Nevertheless, suspension or deposit feeding modes are difficult to separate for these ophiuroids, since the SPOM and SOM were not isotopically discriminated. In other seasons, although stable isotope analysis highlighted that organic matter in the ophiuroid diets is apparently derived from sediment, fatty acids provide evidence that the use of food sources varies between species and locations to some degree.

As previously reported for several small invertebrates (Fujiwara \& Highsmith 1997, Kamermans et al. 2002, Catenazzi \& Donnelly 2007, Dubois et al. 2007b,c, Prato et al. 2012), our results support the relative importance of Ulva spp. as a direct or indirect food source to the ophiuroid diet. During the summer and fall in the Bay of Douarnenez, the isotopic signatures $\left(\delta^{13} \mathrm{C}\right.$ and $\left.\delta^{15} \mathrm{~N}\right)$ of the ophiuroids revealed a contribution of Ulva sp. to their diet. During the fall in the inshore zone of Douarnenez as well as in spring inside the bays, despite low levels of 18:2n-6 and $18: 3 n-3$, a slight increase of these fatty acids was observed for the 2 ophiuroid species compared to those observed outside. This is corroborated by nonnegligible levels of the fatty acids 16:3n-3 and 16:4n-3 observed mostly in $O$. nigra, supporting a green macrophyte dietary origin (Fleurence et al. 1994, Khotimchenko et al. 2002).

It is therefore likely that decomposing Ulva sp. locally contributed to the diet of O. nigra, especially in the Bay of Douarnenez. This seems consistent since elevated levels of bacterial inputs with the fatty acid trans-16:1n-13 were observed in $O$. nigra. In shallow coastal areas, microbial processes become dominant during deposition and decomposition of macroalgal blooms at the sediment interface (Lomstein et al. 2006). Decomposing Ulva sp. could have resulted in the oxidation of $18: 2 n-6$ and $18: 3 n-3$ as reported for seagrass (Tenore et al. 1984, Kharlamenko et al. 2001, Alfaro et al. 2006). Such a phenomenon would potentially lead to an underestimation of the contribution of Ulva sp. to the ophiuroid diet. Benthic invertebrates have the capacity to significantly modify their dietary fatty acids. This is supported by feeding experiments on sea urchins, which revealed that $18: 2 n-6$ and $18: 3 n-3$ decreased in abundance from algae (source) to urchins (consumers), indicating that these fatty acids were affected by consumer metabolism (Castell et al. 2004, Kelly et al. 2009). As recommended by Kelly \& Scheibling (2012), further controlled feeding experiments are necessary to distinguish dietary tracer fatty acids from those that are modified by the consumer.

The relationship between $18: 1 \mathrm{n}-9 / 18: 1 \mathrm{n}-7$ and $\delta^{15} \mathrm{~N}$ (up to $11.4 \%$ ) clearly showed that $O$. nigra occupies a higher trophic position in the BS site compared to those recorded in other locations. This suggests a higher contribution of animal material to its diet, other than that of copepod origin, since levels of the fatty acid 20:1n-11 were low at this location.

This study demonstrates that the cross-validation of isotope and fatty acid biomarkers is a powerful tool to investigate some aspects of the feeding ecology of benthic organisms, here applied to $O$. nigra and $O$. fragilis. Although our findings are in accordance with the results of previous studies reported for these species elsewhere (Mc Kenzie et al. 2000), our results clearly suggest that the trophic plasticity of $O$. nigra 
allows adaptation to fluctuating food sources and expansion of its trophic niche in order to gain a competitive advantage over $O$. fragilis.

Acknowledgements. This work was funded by the national program EC2CO and by the Parc Naturel Marin d'Iroise (PNMI). The authors thank divers, especially X. Caisey, Y. Turpin, A. Besnier, S. Bregeon and F. Goulot for diving logistics and collecting samples during the field survey. We thank J. D. Gaffet for helping in sample preparation. We thank Kimberlee L. Sparks (Cornell University, NY, USA) for stable isotope analyses and Dr. Fabienne Legrand (LEMAR, UMR CNRS IRD 6539, IUEM Brest) for fatty acid identifications in mass spectrometry. We thank ('baie dankie'!) Dr. Julie Deshayes (CNRS IRD, UCT) for editing an earlier version of the manuscript.

\section{LITERATURE CITED}

- Ackman RG, Sebedio JL, Kovacs MIP (1980) Role of eicosenoic and docosenoic fatty acids in freshwater and marine lipids. Mar Chem 9:157-164

Alfaro AC, Thomas F, Sergent L, Duxbury M (2006) Identification of trophic interactions within an estuarine food web (northern New Zealand) using fatty acid biomarkers and stable isotopes. Estuar Coast Shelf Sci 70:271-286

> Allen JR (1998) Suspension feeding in the brittle-star Ophiothrix fragilis: efficiency of particle retention and implications for the use of encounter-rate models. Mar Biol 132: 383-390

Aronson RB (1989) Brittlestar beds: low-predation anachronisms in the British Isles. Ecology 70:856-865

Auel H, Harjes M, de Rocha R, Stübing D, Hagen W (2002) Lipid biomarkers indicate different ecological niches and trophic relationships of the Arctic hyperiid amphipods Themisto abyssorum and T. libellulua. Polar Biol 25: 374-383

Biandolino F, Prato E, Carappo C (2008) Preliminary investigation on the phytoplankton contribution to the mussel diet on the basis of fatty acids analysis. J Mar Biol Assoc UK 88:1009-1017

Blanchet-Aurigny A, Dubois SF, Hily C, Rochette S, Le Goaster E, Guillou M (2012a) Multi-decadal changes in two co-occurring ophiuroid populations. Mar Ecol Prog Ser 460:79-90

Blanchet-Aurigny A, Guillou M, Pernet F, Dubois SF (2012b) Tissue-diet discrimination factors of isotopic ratios $\left(\Delta \delta^{13} \mathrm{C}\right.$ and $\Delta \delta^{15} \mathrm{~N}$ ) in two brittle star species: effect of reproductive state, diet and tissue composition. J Exp Mar Biol Ecol 426-427:68-77

Boos K (2012) Tooth morphology and food processing in Ophiothrix fragilis (Abildgaard, in O.F. Müller, 1789) and Ophiura albida Forbes, 1839 (Echinodermata: Ophiuroidea). Zoosymposia 7:111-119

Brind'Amour A, Dubois SF (2013) Isotopic diversity indices: How sensitive to food web structure? PLoS ONE 8: e84198

> Budge SM, Parrish CC (1998) Lipid biogeochemistry of plankton, settling matter and sediments in Trinity Bay, Newfoundland. II. Fatty acids. Org Geochem 29: 1547-1559

Budge SM, Iverson SJ, Bowen WD, Ackman RG (2002)
Among- and within-species variability in fatty acid signatures of marine fish and invertebrates on the Scotian Shelf, Georges Bank, and southern Gulf of St. Lawrence. Can J Fish Aquat Sci 59:886-898

> Carvalho S, Pereira P, Pereira F, Pablo F, de Pablo H, Vale C, Gaspar MB (2011) Factors structuring temporal and spatial dynamics of macrobenthic communities in a eutrophic coastal lagoon (Óbidos lagoon, Portugal). Mar Environ Res 71:97-110

> Castell JD, Kennedy EJ, Robinson SMC, Parsons GJ, Blair TJ, Gonzalez-Duran E (2004) Effect of dietary lipids on fatty acid composition and metabolism in juvenile green sea urchins (Strongylocentrotus droebachiensis). Aquaculture 242:417-435

> Catenazzi A, Donnelly MA (2007) Role of supratidal invertebrates in the decomposition of beach-cast green algae Ulva sp. Mar Ecol Prog Ser 349:33-42

CEVA (Centre d'Etude et de Valorisation des Algues) (2011) Note de synthèse CEVA-Caractérisation de la marée verte en baie de Douarnenez et détermination des objectifs de la qualité de l'eau à atteindre, octobre 2011. http://www.sagebaiededouarnenez.org/site/wp-content/ uploads/2012/01/1-CEVA-ulves-Baie-de-Douarnenez. pdf

$>$ Dalsgaard J, St John M, Kattner G, Müller-Navara D, Hagen W (2003) Fatty acid trophic markers in the pelagic marine environment. Adv Mar Biol 46:225-340

> DeNiro M, Epstein S (1978) Influence of diet on the distribution of carbon isotopes in animals. Geochim Cosmochim Acta 42:495-506

> Dethier MN, Sosik E, Galloway AWE, Duggins DO, Simenstad CA (2013) Addressing assumptions: variation in stable isotopes and fatty acids of marine macrophytes can confound conclusions of food web studies. Mar Ecol Prog Ser 478:1-14

Dion P, Le Bozec S (1996) The French Atlantic coasts. In: Shramm W, Nienhuis PH (eds) Marine benthic vegetation: recent changes and the effects of eutrophication. Springer-Verlag, Berlin, p 251-264

> Drazen JC, Phleger CF, Guest MA, Nichols PD (2008) Lipid, sterols and fatty acid composition of abyssal holothurians and ophiuroids from the north-east Pacific Ocean: food web implications. Comp Biochem Physiol B 151:79-87

Dubois SF, Colombo F (2014) How picky can you be? Temporal variations in trophic niches of co-occurring suspension-feeding species. Food Webs 1:1-9

> Dubois SF, Grall J (2013) Contributions to the 8th International Conference on Applications of Stable Isotope Techniques to Ecological Studies (ISOECOL), Brest, France, 20-24 August 2012. Isotopes Environ Health Stud 49:293-294

- Dubois S, Blin JL, Bouchaud B, Lefebvre S (2007a) Isotope trophic step fractionation of suspension-feeding species: implications for food partitioning in coastal ecosystem. J Exp Mar Biol Ecol 351:121-128

> Dubois S, Orvain F, Marin-Léal JC, Ropert M, Lefebvre S (2007b) Small-scale spatial variability of food partitioning between cultivated oysters and associated suspension feeding species, as revealed by stable isotopes. Mar Ecol Prog Ser 336:151-160

> Dubois S, Marin-Léal JC, Ropert M, Lefebvre S (2007c) Effects of oyster farming on macrofaunal assemblages associated with Lanice conchilega tubeworm populations: a trophic analysis using natural stable isotopes. Aquaculture 271:336-349 
Dunstan GA, Volkman JK, Jeffrey SW, Barrett SM (1992) Biochemical composition of microalgae from the green algal classes Chlorophycae and Prasinophycae. 2. Lipid classes and fatty acids. J Exp Mar Biol Ecol 161:115-134

Eisen MB, Spellman PT, Brown PO, Botstein D (1998) Cluster analysis and display of genome-wide expression patterns. Proc Natl Acad Sci USA 95:14863-14868

> El-Sabaawi R, Dower JF, Kainz M, Mazumder A (2009) Interannual variability in fatty acid composition of the copepod Neocalanus plumchrus in the strait of Georgia, British Columbia. Mar Ecol Prog Ser 382:151-161

El-Sabaawi R, Sastri AR, Dower JF, Mazumder A (2010) Deciphering the seasonal cycle of copepod trophic dynamics in the strait of Georgia, Canada, using stable isotopes and fatty acids. Estuaries Coasts 33:738-752

> Fleurence J, Gutbier G, Mabeau S, Leray C (1994) Fatty acids from 11 marine macroalgae of the French Brittany coast. J Appl Phycol 6:527-532

Folch J, Lees M, Sloanne-Stanlez GH (1957) A simple method for the isolation and purification of total lipids from animal tissues. J Biol Chem 226:497-509

Fontaine AR (1965) The feeding mechanisms of the Ophiuroid Ophiocomina nigra. J Mar Biol Assoc UK 45:373-385

Fujiwara M, Highsmith RC (1997) Harpacticoid copepods: potential link between inbound adult salmon and outbound juvenile salmon. Mar Ecol Prog Ser 158:205-216

> Graeve M, Kattner G, Piepenburg D (1997) Lipids in Arctic benthos: Does the fatty acid and alcohol composition reflect feeding and trophic interactions? Polar Biol 18: 53-61

Guest MA, Hirst AJ, Nichols PD, Frusther SD (2010) Multiscale spatial variation in stable isotope and fatty acid profiles amongst temperate reef species: implications for design and interpretation of trophic studies. Mar Ecol Prog Ser 410:25-41

Guillou M, Blanchet-Aurigny A, Le Goaster E (2013) Density fluctuations of the ophiuroids Ophiothrix fragilis and Ophiocomina nigra in the Bay of Douarnenez, Brittany, France. Mar Biodivers Rec 6:1-5

Hily C (1989) La mégafaune benthique des fonds meubles de la rade de Brest: pré-échantillonnage par vidéo sousmarine. Cah Biol Mar 30:433-454

- Hily C (1991) Is the activity of benthic suspension feeders a factor controlling water quality in the Bay of Brest? Mar Ecol Prog Ser 69:179-188

Hughes DJ (1998) Subtidal brittlestar beds (volume IV). An overview of dynamics and sensitivity characteristics for conservation management of marine SACs. Scottish Association for Marine Science (SAMS), UK Marine SACs Project

> Iken K, Brey T, Wand U, Voigt J, Junghans P (2001) Food web structure of the benthic community at the Porcupine Abyssal Plain (NE Atlantic): a stable isotope analysis. Prog Oceanogr 50:383-405

> Jackson AL, Inger R, Parnell AC, Bearhop S (2011) Comparing isotopic niche widths among and within communities: SIBER-Stable Isotope Bayesian Ellipses in R. J Anim Ecol 80:595-602

Kamermans P, Malta EJ, Vershuure JM, Schrijvers L, Lentz LF, Lien ATA (2002) Effect of grazing by isopods and amphipods on growth of Ulva spp. (Chlorophyta). Aquat Ecol 36:425-433

Kattner G, Graeve M, Hagen W (2012) Energy reserves of Southern Ocean copepods: Triacylglycerols with unusually long-chain monounsaturated fatty acids. Mar Chem
138-139:7-12

Kelly JR, Scheibling RE (2012) Fatty acids as dietary tracers in benthic food webs. Mar Ecol Prog Ser 446:1-22

- Kelly JR, Scheibling RE, Iverson SJ, Gagnon P (2008) Fatty acid profiles in the gonads of the sea urchin Strongylocentrotus droebachiensis on natural algal diets. Mar Ecol Prog Ser 373:1-9

Kelly JR, Scheibling RE, Iverson SJ (2009) Fatty acids tracers for native and invasive macroalgae in an experimental food web. Mar Ecol Prog Ser 391:53-63

Kharlamenko VI, Kiyashko SI, Imbs AB, Vyshkvartzev DI (2001) Identification of food sources of invertebrates from the seagrass Zostera marina community using carbon and sulfur stable isotope ratio and fatty acid analyses. Mar Ecol Prog Ser 220:103-117

Khotimchenko SV, Vaskovsky VE, Titlyanova TV (2002) Fatty acids of marine algae from the pacific coast of north California. Bot Mar 45:17-22

Kojadinovic J, Richard P, Le Corre M, Cosson RP, Bustamante P (2008) Effects of lipid extraction on $\delta^{13} \mathrm{C}$ and $\delta^{15} \mathrm{~N}$ values in seabird muscle, liver and feathers. Waterbirds 31:169-178

> Layman CA, Araujo MS, Boucek R, Hammerschlag-Peyer $\mathrm{CM}$ and others (2012) Applying stable isotopes to examine food-web structure: an overview of analytical tools. Biol Rev Camb Philos Soc 87:545-562

> Le Pape O, Del Amo Y, Cann P, Ménesguen A, Aminot A, Quéguiner B, Tréguer P (1996) Resistance of a coastal ecosystem under increasing eutrophic conditions: the Bay of Brest (France), a semi-enclosed zone of western Europe. Cont Shelf Res 16:1885-1907

> Lee RF, Nevenzel JC, Paffenhofer GA (1971) Importance of wax esters and other lipids in the marine food chain: phytoplankton and copepods. Mar Biol 9:99-108

> Lefebvre S, Marin Leal JC, Dubois S, Orvain S and others (2009) Seasonal dynamics of trophic relationships among co-occurring suspension-feeders in two shellfish culture dominated ecosystems. Estuar Coast Shelf Sci 82: 415-425

Lomstein BA, Bonne Guldberg LB, Amtoft Neubauer AT, Hansen $\mathrm{J}$ and others (2006) Benthic decomposition of Ulva lactuca: a controlled laboratory experiment. Aquat Bot 85:271-281

Maazouzi C, Masson G, Izquierdo MS, Pihan JC (2007) Fatty acid composition of the amphipod Dikerogammarus villosus: feeding strategies and trophic links. Comp Biochem Physiol Part A Mol Integr Physiol 147:868-875

> Mann KH (1988) Production and use of detritus in various freshwater, estuarine, and coastal marine ecosystems. Limnol Oceanogr 33:910-930

Marty Y, Delaunay F, Moal J, Samain JF (1992) Changes in the fatty acid composition of Pecten maximus (L.) during larval development. J Exp Mar Biol Ecol 163:221-234

McKenzie JD, Black KD, Kelly MS, Newton LC and others (2000) Comparisons of fatty acid and stable isotope ratios in symbiotic and non-symbiotic brittlestars from Oban Bay, Scotland. J Mar Biol Assoc UK 80:311-320

> Ménesguen A, Cugier P, Leblond I (2006) A new numerical technique for tracking chemical species in a multisource, coastal ecosystem applied to nitrogen causing Ulva blooms in the Bay of Brest (France). Limnol Oceanogr 51: 591-601

> Merceron M, Antoine V, Auby I, Morand P (2007) In situ growth potential of the subtidal part of green tide forming Ulva spp. stocks. Sci Total Environ 384:293-305 
Metcalfe LD, Schmitz AA (1961) The rapid preparation of fatty acid esters for gas chromatographic analysis. Anal Chem 33:363-364

Minagawa M, Wada E (1984) Stepwise enrichment of ${ }^{15} \mathrm{~N}$ along food chains: further evidence and the relation between ${ }^{15} \mathrm{~N}$ and animal age. Geochim Cosmochim Acta 48:1135-1140

Nagabhushanam AK, Colman JS (1959) Carrion-eating by ophiuroids. Nature 184:285

> Nelson MM, Phleger CF, Nichols PD (2002) Seasonal lipid composition in macroalgae of the northeastern Pacific Ocean. Bot Mar 45:58-65

Nichols PD, Klumpp DW, Johns RB (1982) Lipid components of the seagrasses Posidonia australis and Heterozostera tasmanica as indicators of carbon source. Phytochemistry 21:1613-1621

Pernet F, Malet N, Pastoureaud A, Vaquer A, Quéré C, Dubroca L (2012) Marine diatoms sustain growth of bivalves in a Mediterranean lagoon. J Sea Res 68:20-32

Pernet F, Lagarde F, Jeannée N, Daigle G and others (2014) Spatial and temporal dynamics of mass mortalities in oysters is influenced by energetic reserves and food quality. PLoS ONE 9:e88469

Peterson BJ (1999) Stable isotopes as tracers of organic matter input and transfer in benthic food webs: a review. Acta Oecol 20:479-487

Pommier J, Frenette JJ, Glémet H (2010) Relating RNA: DNA ratio in Eurytemora affinis to seston fatty acids in a highly dynamic environment. Mar Ecol Prog Ser 400: 143-154

Prato E, Danieli A, Maffia M, Biandolino F (2012) Lipids contents and fatty acid compositions of Idotea baltica and Sphaeroma serratum (Crustacea: Isopoda) as indicators of food sources. Zool Stud 51:38-50

R Development Core Team (2012) R: a language and environment for statistical computing. R Foundation for Statistical Computing, Vienna

Ratnayake WN, Ackman RG (1979) Fatty alcohols in capelin, herring and mackerel oils and muscle lipids: I. Fatty alcohol details linking dietary copepod fat with certain fish depot fats. Lipids 14:795-803

Sargent JR, Whittle JJ (1981) Lipids and hydrocarbons in the marine food web. In: Longhurst AR (ed) Analysis of marine ecosystems. Academic Press, London, p 491-553

Editorial responsibility: Yves Cherel,

Villiers-en-Bois, France
Sewell MA, Levitan DR (1992) Fertilization success during a natural spawning of the dendrochirote sea cucumber Cucumaria miniata. Bull Mar Sci 51:161-166

Stevens CJ, Deibel D, Parrish C (2004) Copepod omnivory in the North Water Polynya (Baffin Bay) during autumn: spatial patterns in lipid composition. Deep-Sea Res I Oceanogr Res Pap 51:1637-1658

Takagi T, Kaneniwa M, Itabashi Y (1986) Fatty acids in Crinoidea and Ophiuroidea: occurrence of all-cis-6,9,12, 15,18, 21-tetracosahexaenoic acid. Lipids 21:430-433

Tenore KR, Hanson RB, McClain J, MacCubin AE, Hodson $\mathrm{RE}$ (1984) Changes in composition and nutrition value to a benthic deposit feeder of decomposing detritus pool. Bull Mar Sci 35:299-311

Terasaki M, Itabashi Y, Suzuki T, Nishimura K (2002) An improved method for determining the composition of FFA in red tide flagellates by RP-HPLC with fluorescence detection. J Am Oil Chem Soc 79:1181-1186

Thrush SF, Cummings VJ (2011) Massive iceberg alteration in primary food resources and change in benthic communities at Cape Evans, Antarctica. Mar Ecol 32:289-299

Uthicke S, Schaffelke B, Byrne M (2009) A boom-bust phylum? Ecological and evolutionary consequences of dense variations in echinoderms. Ecol Monogr 79:3-24

> Veloza AJ, Chu FLE, Tang KW (2006) Trophic modification of essential fatty acids by heterotrophic protists and its effects on the fatty acid composition of the copepod Acartia tonsa. Mar Biol 148:779-788

Vevers HG (1956) Observations on feeding mechanisms in some ophiuroids. Proc Zool Soc Lond 126:484-485

Volkman JK, Johns RB, Gillan FT, Perry GJ (1980) Microbial lipids of an intertidal sediment. I. Fatty acids and hydrocarbons. Geochim Cosmochim Acta 44:1133-1143

Ward J (1963) Hierarchical grouping to optimize an objective function. J Am Stat Assoc 58:236-244

Warner G (1982) Food and feeding mechanisms: Ophiuroidea. In: Jangoux M, Lawrence JM (eds) Echinoderm nutrition. A. A. Balkema, Rotterdam, p 161-181

Warner GF, Woodley JD (1975) Suspension-feeding in the brittle-star Ophiothrix fragilis. J Mar Biol Assoc UK 55: 199-210

Würzberg L, Peters J, Schüller M, Brandt A (2011) Diet insights of deep-sea polychaetes from fatty acid analyses. Deep-Sea Res II 58:153-162

Submitted: April 4, 2014; Accepted: December 16, 2014

Proofs received from author(s): March 18, 2015 